\title{
FEMINIST PHILOSOPHY OF DISABILITY: A GENEALOGICAL INTERVENTION
}

\author{
Shelley L. Tremain
}

\begin{abstract}
This article is a feminist intervention into the ways that disability is researched and represented in philosophy at present. Nevertheless, some of the claims that I make over the course of the article are also pertinent to the marginalization in philosophy of other areas of inquiry, including philosophy of race, feminist philosophy more broadly, indigenous philosophies, and LGBTQI philosophy. Although the discipline of philosophy largely continues to operate under the guise of neutrality, rationality, and objectivity, the institutionalized structure of the discipline implicitly and explicitly promotes certain ontologies, epistemologies, and methodologies as bona fide philosophy, while casting the ontologies, epistemologies, and methodologies of marginalized philosophies as mere simulacra of allegedly fundamental ways of knowing and doing philosophy and thus rendering these marginalized philosophies more or less expendable. This article is designed to show that legitimized philosophical discourses are vital mechanisms in the problematization of disability.
\end{abstract}

\section{INTRODUCTION}

This article is a feminist intervention into the ways that disability is researched and represented in philosophy at present, a feminist intervention distinctly designed to subvert the dominance of individualized and medicalized approaches to disability and the marginalization of critical philosophical work on disability. Nevertheless, some of the claims that I make over the

Shelley L. Tremain holds a PhD in philosophy, has taught in Canada, the U.S., and Australia, and has published on a range of topics, including philosophy of disability, Foucault, ableism in feminist philosophy, and genetic technologies. Tremain is the author of Foucault and Feminist Philosophy of Disability (University of Michigan Press, 2017), which was awarded the 2016 Tobin Siebers Prize for Disability Studies in the Humanities, and editor of Foucault and the Government of Disability (University of Michigan Press, 2005; 2015). 
course of the article are also pertinent to the marginalization in philosophy of other areas of inquiry, including philosophy of race, feminist philosophy more broadly, indigenous philosophies, and LGBTQI philosophy. For although the discipline of philosophy largely continues to operate under the guise of neutrality, rationality, and objectivity, the institutionalized structure of the discipline implicitly and explicitly promotes certain ontologies, epistemologies, and methodologies as bona fide philosophy, while casting the ontologies, epistemologies, and methodologies of marginalized philosophies as mere simulacra of allegedly fundamental ways of knowing and doing philosophy and thus rendering these marginalized philosophies more or less expendable.

A certain limited number of subfields of philosophy - metaphysics, ethics, logic, epistemology, and philosophy of language - are widely regarded in the contemporary discipline of philosophy as foundational to it, uniquely distinguishing it from other disciplines of research and teaching and reaffirming its self-ascribed status as "the queen of the sciences." Philosophers who continue to hold this conventional view of philosophy maintain that these subfields are the necessary, unchanging, and "core" elements of philosophy, while other subfields of philosophical inquiry - such as philosophy of race and feminist philosophy - are applications and contingent derivatives of these foundational subfields. That is, philosophers who understand the structure and practice of philosophy in this conventional way take for granted that the former subfields are ontologically and epistemologically prior to the latter subfields and, indeed, render the latter subfields conceivable in the first place. For philosophers who distinguish in this way between "core" subfields of philosophy and "applied" subfields of philosophy, the questions and concerns that make up the former subfields are generally regarded as timeless, disinterested, and universal in character, and, alternatively, the questions and concerns that constitute the latter subfields are generally taken to be accidental, interested, and partial.

This conventional understanding of philosophy conditions PhilPapers: Online Research in Philosophy (n.d.), the increasingly influential database of research and writing in philosophy whose architecture is nevertheless purported to be value neutral and merely descriptive of philosophy's authentic nature. The content of the database is organized into predetermined areas of specialization, subfields, and topics in philosophy that are hierarchically arranged in descending order of importance according to prevailing ideas in the tradition and discipline of Euro-American, Western philosophy about which areas, subfields, and topics: (1) have the most/less philosophical import; (2) have the most/less explanatory power; and (3) should be endowed with the most/less authoritative status. So-called core or 
fundamental areas of the discipline-"Metaphysics and Epistemology," "Value Theory," "Science, Logic, and Mathematics," "History of Western Philosophy," and "Philosophical Traditions"-are designated as the supreme categories on the database and, in turn, other areas of inquiry are designated as subcategories of these supreme categories, or subcategories of the subcategories of the supreme categories, or ("leaf") subcategories of the subcategories of the subcategories of the supreme categories, where a category's distance from the supreme categories is understood to be indicative of the allegedly diminished import and explanatory power that it holds, as well as the relative authority within philosophy of the areas of inquiry that it comprises (Tremain 2013, 2017a, xi-ix). ${ }^{1}$

Against this conventional and biased understanding of the institutional structure and discursive practices of philosophy, I want to argue that the classification of subfields in philosophy, the relations between the classifications of the subfields, and the questions and concerns that these subfields comprise is no mere value-neutral reportage or representation of objective differences, relations, and similarities that await discovery and recognition; rather, classification (and classification systems) in philosophy (as elsewhere) is performative insofar as it contributes to the constitution of the very value-laden resemblances, distinctions, associations, and relationships between phenomena and states of affairs that it puts into place. Although many philosophers continue to represent philosophy as a value neutral, detached, disinterested, and impartial enterprise, political, social, economic, cultural, and institutional force relations influence every aspect of the discipline (and profession) of philosophy. Every philosophical question and concern, as well as every subfield that these questions and concerns constitute, is a politically potent artifact of historically contingent and culturally specific discourse. As contingent artifacts of discourse, furthermore, every philosophical question, every philosophical subfield, and every specialization in philosophy has a history, a history that can be traced genealogically (see Tremain 2013, 2017a, ix-xi).

Consider the marginalized location that the emerging subfield of feminist philosophy of disability occupies at present within the current formulation of the PhilPapers database. Within the constitutive categories of the database, that is, feminist philosophical work on disability is situated under the rubric of a "leaf" subcategory - namely, "Feminism: Disability" - that

\footnotetext{
${ }^{1}$ Some of my remarks in this article, including my remarks about the PhilPapers database, have been reproduced or adapted from my book Foucault and Feminist Philosophy of Disability (Ann Arbor: University of Michigan Press, 2017) and are reprinted with permission from the University of Michigan Press.
} 
is subordinate to the subcategory of "Topics in Feminist Philosophy," a subcategory of the superior category of "Philosophy of Gender, Race, and Sexuality" that is, in turn, a subcategory of the supreme category of "Value Theory." In the schema of the PhilPapers database, in other words, feminist philosophy of disability is represented as on par with "topics" in feminist philosophy such as "Autonomy," "Love," "Identity Politics," and "Reproduction," rather than represented as on par with, an element of, and in relationship with other apparatuses of identity and subjectionnamely, gender, race, and sexuality - in a more comprehensive category of "Philosophy of Gender, Race, Sexuality, and Disability," to which the subcategory of "Topics in Feminist Philosophy" would in turn be subordinate. Although the superior category of "Philosophy of Gender, Race, and Sexuality" includes subcategories of "Philosophy of Gender," "Philosophy of Race," and "Philosophy of Sexuality," it does not encompass an offspring category of "Philosophy of Disability." There is, of course, no objective and value-neutral explanation for why feminist philosophy of disability has been so categorized in the PhilPapers database. Rather, the relegated status conferred upon feminist philosophy of disability in the database reflects a political decision, a political decision that, among other things, precludes and even prevents the incorporation of disability into intersectional or other integrated analyses, thereby reinforcing depoliticized conceptions of disability in philosophy and contributing to the marginalization and diminution of critical work on disability within the subfield of feminist philosophy and the discipline more generally (see Tremain 2013, 2017a, ix-xi).

The motivation to attribute this relegated status to feminist philosophical work on disability becomes even more discernible when one considers how disability is classified elsewhere in the database. For example, "leaf" sub-sub-sub-categories with respect to disability can be found under the broader sub-sub-category of "Biomedical Ethics," alongside and on par with items such as "Drugs," "Death and Dying," and "Neuroethics," as well as under the sub-sub-category of "Social Ethics," alongside and on par with items such as "Deception" and "Friendship." These "leaf" sub-sub-sub-categories of "Disability" are, ultimately, derivatives of the superior (sub-)sub-category of "Applied Ethics," itself a subcategory of the supreme category of "Value Theory." I want to point out, therefore, that the company that the ("leaf" sub-sub-)sub-category of "Disability" keeps in the former location on the database - "Biomedical Ethics"- both reinforces individualized and medicalized conceptions of disability and minimizes the social, political, and discursive significance of disability, especially in light of 
how subordinate the positioning of "Disability" is within the database as a whole. I want to point out, furthermore, that the almost exclusive classification and categorization of work on disability under the database's category of "Value Theory" relies on reductive assumptions according to which the only worthwhile inquiries about disability in which philosophers engage are "ethical" in nature, effectively obscuring the fact that much of the work done in philosophy of disability concentrates on epistemological and metaphysical questions about the phenomena (see, e.g., Tremain 2013, 2017a; also see Tremain 2015).

The genealogy of feminist philosophy of disability that I have begun to unravel in this article (and unravelled in the 2017 book from which this article is adapted) aims to resist and disrupt the conventional - that is, individualized and medicalized - understanding of disability that most philosophers presuppose, drawing upon Michel Foucault's toolbox of insights to do so. Although mainstream philosophers variously allege that their claims about disability are value neutral and disinterested, a feminist philosophy of disability that draws on Foucault openly acknowledges the political character of both its claims with respect to disability and the presuppositions on which they rely, arguing (with Foucault) that discursive practices are always already the products of historically contingent and situated force relations.

A politically engaged and informed philosophy of disability that uses Foucault's insights will be unpopular in some corners of philosophy. For while Foucauldian insights have made significant inroads elsewhere in the humanities and social sciences, they remain starkly marginalized within philosophy, a state of affairs that can be attributed to a variety of factors, including the continued dominance of the methods and approaches of "analytic" philosophy; the persistent disdain amongst mainstream (analytic) philosophers for "postmodernism" and relativism, both of which many philosophers disparagingly affiliate with Foucault; the narrow(ing) concentration of the prevailing subject matter and techniques of philosophy; the increasingly close association between science and philosophy; and the otherwise limited theoretical, discursive, and political scope of much of the research that philosophers currently produce. In Foucault and Feminist Philosophy of Disability (2017a), I directly address these issues at length; thus, I largely bypass them in this article. My argument in what follows is nevertheless designed to show that Foucault's body of work offers the most sophisticated and politically astute tools with which to articulate a feminist philosophy of disability that takes account of its own historical and cultural specificity and contingency. 


\section{GENEALOGY, PROBLEMATIZATION, AND DISABILITY}

Introduced by Friedrich Nietzsche in A Genealogy of Morals ([1887] 1999) and adapted by Foucault in works such as Discipline and Punish: The Birth of the Prison (1977a) and A History of Sexuality, Volume One: An Introduction (1978), genealogy is a historicized approach to philosophical inquiry, distinct from the ahistorical conceptual analysis, deductive reasoning, and logical argumentation that characterizes mainstream analytic philosophy. Foucault adopted genealogy to critically inquire into the history of necessity on a given topic and the historical emergence of the necessary conditions for states of affairs, underscoring the importance to such an approach of contingency and of questioning what has been taken for granted as self-evident. Foucault's genealogies - which he variously referred to as "histories of the present" and "historical ontologies of ourselves" - are concerned with questions about the conditions of possibility for who we are now, that is, questions about how our current ways of thinking and acting came into being (Foucault 1997).

The genealogist does not reject knowledge or appeal to, or even celebrate, some immediate experience that knowledge has yet to capture. Rather, genealogies, Foucault (1980b) explained, "are about the insurrection of knowledges....An insurrection against the centralizing power effects that are bound up with the institutionalization and workings of any scientific discourse organized in a society such as ours." Genealogy, Foucault wrote, is an "attempt to desubjugate historical knowledges...to enable them to oppose and struggle against the coercion of a unitary, formal, and scientific theoretical discourse" (2003b, 9). He argued, furthermore, that criticism performs its work by uncovering and restoring these subjugated, unqualified, and even directly disqualified knowledges. Genealogies exhume these subjugated knowledges, exhume these obsolete and even archaic discourses, events, and institutional practices, in order that we can understand the historically contingent character of the self-understandings and self-perceptions that we hold in the present.

Foucault's genealogies were inquiries into the "problematization" of phenomena-including abnormality, perversion, sexuality, and madness - in the present, inquiries that attempted to uncover how "solutions" to certain problems have been constructed, in addition to how these different solutions resulted from the problematization of that given state of affairs in the first place (2003a, 20-24). Just as Foucault's genealogical studies of the problematization of abnormality, perversion, sexuality, and madness (among other things) were not positivistic appeals to a form of science that more accurately represents these phenomena, nor were these studies 
intended to provide normative responses or solutions to these phenomena. Rather, Foucault's genealogical studies were designed to show how certain phenomena and states of affairs became thinkable, that is, emerged as problems to which solutions came to be sought. Foucault, in response to philosophers who have argued that his nonnormative, genealogical approach of inquiry cannot distinguish between acceptable and unacceptable forms of power (e.g., Fraser 1989, 31), explained the approach in this way: "In a sense, I am a moralist, insofar as I believe that one of the tasks, one of the meanings of human existence - the source of human freedom - is never to accept anything as definitive, untouchable, obvious, or immobile" (Foucault $1988,1)$. Foucault's historical method of critical inquiry requires that we ask about the values, purposes, and aims of our current practices, the circumstances of their emergence, and the historically contingent forms of power that contribute to their constitution (also see Hall 2015, 2016).

My feminist philosophical work on disability - which, in some respects, extends Foucault's own genealogical examinations of the problematization of abnormality, madness, perversion, and other phenomena commonly associated with disability - is thus most aptly characterized as a feminist genealogical inquiry into the problematization of disability in philosophy (see, e.g., Tremain 2006; 2010; 2015; 2017a). For just as Foucault's genealogical studies of the problematization of abnormality, perversion, sexuality, and madness (among other things) were not intended to provide normative responses or solutions to these phenomena, my problematization of disability does not offer an explicitly normative feminist proposal or response to the phenomena of disability. Such a given proposal or response would presuppose that there is a certain definitive solution to the "problem" of disability. Instead, my feminist philosophical inquiry into the problematization of disability is designed in large part to indicate how a certain historically and culturally specific regime of power - namely, biopower - has produced certain acts, practices, subjectivities, bodies, relations, and so on as a problem for the present, as well as to indicate the role that philosophy has played and continues to play in the elaboration of this problem. In other words, my aim is to articulate an analytically robust and empirically grounded feminist philosophy of disability that interrogates the historical conditions of possibility for its own articulation.

Due to the resurgence of work on social justice that the publication of John Rawls's A Theory of Justice (1971) precipitated, as well as to the emergence and expansion of the subfields of bioethics and cognitive science, discussions about disability have become increasingly prevalent in mainstream philosophy. Since the mid-twentieth century, that is, mainstream 
philosophers have engaged in philosophical discussions about disability formulated around questions such as these: What (if anything) does society owe to disabled people? How should society compensate disabled people for their natural disadvantages and brute bad luck? On what grounds is it justifiable to euthanize disabled people? Is it morally permissible to conduct experiments on cognitively disabled research subjects? What can we learn about the (normal) mind from the fact that "people with autism" lack a theory of mind? What can we learn about the operations of the (normal) brain, its emotions, perceptions, and so on, from study of people who have experienced brain injuries?

Notwithstanding the apparent variety of questions that mainstream philosophers throughout the discipline have asked about disability, the cluster of motivational assumptions that underpins their inquiries takes for granted the metaphysical status and epistemological character of the category of disability, casting disability as a self-evident designation that science and medicine can accurately represent. On the terms of these assumptions, disability is a prediscursive, transcultural, and transhistorical disadvantage, an objective human defect, that is, a nonaccidental, biological human property, attribute, or characteristic that ought to be prevented, corrected, eliminated, or cured. For example, Rawls, because he assumed that disability is a self-evidently natural defect, that is, because Rawls assumed that disability is a prediscursive, biomedical phenomenon, he excluded consideration of it from his theory of justice, arguing that "normal and cooperating" members of society should choose principles of justice that focus exclusively on what he called "the basic structure of society" rather than seek principles of justice that encompass "special" medical needs and healthcare concerns. In their critical responses to Rawls, Amartya Sen (1979) and Ronald Dworkin (1981a, 1981b) also naturalized and medicalized disability, variously arguing that Rawls erred insofar as he deemed the possession or lack of "natural" characteristics, talents, and capacities to be "morally arbitrary" and thus not the appropriate subject matter of a theory of justice. Dworkin, in his own theory of equality of resources, therefore proposed a hypothetical insurance market that would "compensate for handicaps," that is, make cash payments to "handicapped" people based on their assessments and calculations of the opportunity costs that would accrue to them due to these "natural" handicaps. In another context, I have pointed out that the structure of Dworkin's insurance market would compel disabled people to naturalize the social disadvantages that they confront, effectively violating his own claims about the constraints that the requirements of self-respect place on a theory of justice (see Tremain 1996). That the deleterious 
individualizing and medicalizing assumptions that have conditioned work on disability and social justice in mainstream political philosophy are contestable, that disability might be a historically and culturally specific and contingent social phenomenon, a complex apparatus of power, rather than a natural attribute or property that certain people possess, has not been considered, let alone seriously entertained.

Philosophers who argue that the social inequalities that accrue to disabled people are necessary consequences of a self-evident physiological, or natural, human characteristic (property, difference, or attribute) make certain assumptions about the relation between biology and society that my feminist philosophy of disability is designed to undermine. Dorothy E. Roberts (2016) has distinguished heuristically between two approaches to the question of the relation between biology and society, approaches that she refers to as "the old biosocial science" and "the new biosocial science." As Roberts explains it, the old biosocial science posits that biological differences produce social inequality, whereas the new biosocial science posits that social inequality produces biological differences. The biological determinism of the old biosocial science, she notes, is achieved in these ways: first, the old biosocial science approach separates nature from nurture in order to locate the origins of social inequalities in inherent traits rather than imposed societal structures; second, the old biosocial science postulates that social inequalities are reproduced in the bodies, especially the wombs, of socially disadvantaged people rather than reinvented through unjust ideologies and institutions; third, the old bioscience identifies problems that stem from social inequality as derived from the threats that oppressed people's biology itself poses to society, rather than from structural barriers and state violence imposed upon oppressed people; and fourth, the old bioscience endeavors to intervene and fix perceived biological deficits in the bodies of oppressed people rather than end the structural violence that dehumanizes them and maintains an unjust social order.

Roberts points out that, by contrast, the new biosocial science posits that every single biological element, every single biological process in the human body, every human cell, and everything that happens to a human cell is affected by society. All of life, Roberts remarks, is at once biological and social. There is, in short, no natural body. Genes do not determine anything. Moreover, our brains are plastic, with the ability to be modified by social experience. Epigenetics and social neuroscience, Roberts writes, show that biology is not a separate entity that interacts with the environment; rather, biology is constituted by these interactions (2016; see also Roberts 1998, 2012; Prinz 2012; Gilman and Thomas 2016). With Roberts, various 
authors have argued that critical analyses of biosocial science must consider how claims about the social construction of biological phenomena are produced, in what contexts they are mobilized, and for what political purposes (e.g., Pitts-Taylor 2010). In my work to articulate a feminist philosophy of disability, I aim to critically and genealogically denaturalize and debiologize the phenomena of disability in these ways, among others.

\section{FEMINIST PHILOSOPHIES OF DISABILITY}

Feminist epistemologists and feminist philosophers of science have for quite some time argued that philosophical inquiry must take account of information about the social contexts from which both philosophical questions emerge and responses to them are generated, including the subjectivity and social positioning of any given questioner and respondent. For example, Sandra Harding has argued that information about the subjectivity and social situation of knowers can provide valuable insights into the assumptions and biases on which a given position relies (see, e.g., Harding 1986, 1991, 2015). Harding and other feminist philosophers maintain that any given proposition, argument, or other discursive practice is a product of the enculturation along gendered, racial, classist, and national lines of the subject (or group of subjects) who articulates it and the sociocultural milieu from which it emerges. Harding and other feminist philosophers claim, in short, that there is no such thing as a view from nowhere. To argue this way, Harding and a growing number of feminist (and other) philosophers assume some version of "standpoint epistemology." Feminist standpoint epistemologies variously postulate that people in subordinated social positions have, in virtue of their subordinated social status, understandings of social relations that are superior to - that is, more complete and objective than - the understandings of these relations that members of privileged social groups have (see Harding 1986, 2015; Hartsock 1983; Dotson 2011, 2012). Alison Wylie points out that standpoint theory is an explicitly political social epistemology whose "central and motivating insight is an inversion thesis" (2003, 26). As Wylie explains it,

Those who are subject to structures of domination that systematically marginalize and oppress them may, in fact, be epistemically privileged in some crucial respects. They may know different things, or know things better than those who are comparatively privileged (socially, politically) by virtue of what they experience and how they understand their experience. Feminist standpoint theorists argue that gender is one dimension of social differentiation that may make a difference epistemically. Their aim is to both understand how the systematic partiality of authoritative knowledge arises - specifically, its androcentrism and 
sexism - and to account for the constructive contributions made by those working from marginal standpoints (especially feminist standpoints) in countering this partiality. $(2003,26)$

Feminist philosophers in professional, institutional, and social positions of relative privilege must do more than they have thus far done to put these epistemological and methodological claims to work in practice, especially with respect to disability (and disabled philosophers); nevertheless, feminist philosophical insights about situated knowledges contribute to the background of my feminist philosophy of disability, especially given the commitment of feminist standpoint theorists who-however much they otherwise disagree - concur that standpoint theories must not "presuppose an essentialist definition of the social categories or collectivities in terms of which epistemically relevant standpoints are characterized" (Wylie 2003, 26).

As the previous remarks about feminist standpoint epistemologies indicate, feminist philosophers take a critical approach to many of the methods and values of traditional areas of philosophy, questioning the assumptions and biases on which these areas of philosophy rely and identifying how these assumptions and biases reinforce forms of social subordination, especially with respect to gender. Feminist philosophers of disability (e.g., Silvers 1995; Wendell 1996; Kittay 1999; Carlson 2009; Barnes 2016) variously concentrate on disability, as well as on assumptions and biases about disability on which philosophical claims rely, examining how these assumptions and biases contribute to the social subordination of disabled people. Feminist philosophers of disability also advance approaches to disability that resist and run counter to the conception of disability that prevails in mainstream bioethics, cognitive science, and mainstream political philosophy and ethics, a conception according to which disability is a deficit, personal misfortune, or pathology that necessarily reduces the quality and worth of disabled people's lives and inevitably leads to the social and economic disadvantages that disabled people confront. Insofar as mainstream philosophers such as Rawls have cast disability as a natural, negative, and inert state of affairs in this way, they have largely removed the category of disability from the realm of philosophical inquiry and kept at bay philosophical debate and questioning about its epistemological, ethical, and political status. Feminist philosophers of disability, by contrast, both use and take a critical stance toward the history of philosophy and the contemporary practice of mainstream philosophy to variously elaborate new ways in which to think about disability and about the current social, political, cultural, and economic position of disabled people. They do so by employing the very methods, 
concepts, analytical rigor, and argumentative tools of the Euro-American, Western philosophical tradition and the discipline of philosophy in which they were trained, in addition to critically evaluating these practices and tools through the concepts, political commitments, critical insights, and personal investments that shape feminist, anti-ableist, antiracist, class-conscious, and antiheterosexist theory and practice.

My feminist philosophy of disability relies upon an understanding of disability that distinguishes it from other feminist philosophies and theories of disability. Other feminist philosophies and theories of disability uncritically retain some of the unsavory elements of dominant theoretical approaches to disability insofar as they variously conceive disability as (1) the functional manifestation of an intrinsic characteristic, a biological difference, or a property (attribute) - for example, an impairment - that certain people embody or possess and that gives rise to certain forms of social discrimination against them (e.g., Barnes 2016); or (2) the form of discrimination and oppression imposed upon people who have an intrinsic characteristic, attribute, or property construed as a human difference (e.g., Silvers 1995; Wendell 1996; Kittay 1999); or (3) some combination of (1) and (2), in which the relation between disability (as a functional limitation or form of social oppression) and, say, impairment (as an intrinsic characteristic, a property, or a difference that some people embody or possess) may not be clearly defined or may fluctuate from one context to another context, though, terminologically speaking, emphasis is placed upon the former, that is, disability (e.g., Carlson 2009). Feminist philosophies and theories that assume (1) construe disability as a natural feature of human existence, an aspect of human diversity that has historically been devalued and must be redeemed, revalued, and even celebrated. Feminist philosophies and theories of disability that assume (2) construe disability as a social, economic, and political problem directed at an already-existing group of people. Whereas feminist philosophies and theories of disability that assume (3) tend to be ambiguous about the actual character of disability and are, in some cases, inadvertently self-contradictory (see Tremain 2017a).

I want to point out, furthermore, that although these apparently distinct conceptions of disability diverge from each other in some identifiable ways, they depend upon roughly the same assumptions about the epistemological and ontological status of impairment and disability, as well as upon the same assumptions about social power, including the assumption according to which power is fundamentally repressive and external to preexisting objects upon which it acts. I disagree with all these assumptions. Instead, I maintain, with Foucault, that social power is productive of the objects that it affects rather than first and foremost repressive; that is, power is immanent 
in the objects and practices it affects rather than external to them, as these other (feminist) conceptions of disability assume. In other words, my disagreement with these other feminist conceptions of disability stems from the assumptions about causation that they make and the epistemological and ontological status that they implicitly confer upon the categories of impairment and disability. Whereas other feminist philosophers and theorists of disability variously conceive of disability as the functional outcome of a natural human characteristic, a human variation or difference, an identity, or a form of oppression in relation to which impairment is assumed to be the anterior, or prediscursive, foundation, I regard disability as what Foucault (1980a) referred to as an "apparatus" (dispositif) of relatively recent force relations. Impairment, I contend, is an element of this apparatus produced as its naturalized and naturalizing foundation; that is, impairment is both an effect of and a mechanism of the apparatus of disability (see Tremain 2017a).

A disabled feminist interlocutor might object that my claims according to which (1) disability is an apparatus of power and (2) impairment is produced as the naturalized foundation of this apparatus (3) deny the materiality of the impaired body. That is, a disabled feminist interlocutor might believe that a charge that disabled feminists (among others) have directed at the British social model of disability (BSM) - namely, that the BSM denies impairment and the body - should also be directed at the claims according to which disability is an apparatus of power and impairment is its naturalized foundation. In other contexts, I identify numerous important differences between, on the one side, the conception of impairment and disability that the BSM assumes and, on the other, the conception of disability as an apparatus, in Foucault's sense, differences that the hypothetical charge collapses. As I point out in these other contexts, furthermore, the objection misconstrues Foucault's arguments about the discursive constitution of the body. For Foucault did not deny the materiality of the body and its experiences; rather, Foucault was concerned to show that "the body" and its material experiences cannot be dissociated from the historically contingent practices that bring it into being, that is, bring it into being as that kind of thing: as impaired, as racialized, gendered, sexed, and so on (see Tremain 2001; 2015; 2010; 2015; 2017a). Foucault explained his genealogical approach to the body in this way:

We believe that feelings are immutable, but every sentiment, particularly the noblest and most disinterested, has a history. We believe in the dull constancy of instinctual life and imagine that it continues to exert its force indiscriminately in the present as it did in the past. . . We believe, in any event, that the body 
obeys the exclusive laws of physiology and that it escapes the influence of history, but this too is false. (1977b, 153)

\section{THE APPARATUS OF DISABILITY}

Given the persistence of charges according to which Foucauldian approaches to disability replicate problems of the BSM, a fuller explanation of the idea of disability an apparatus seems apropos. In "The Confession of the Flesh," Foucault (1980a, 194) defined an apparatus (dispositif) as a heterogeneous and interconnected ensemble of discourses, institutions, architectural forms, regulatory decisions, laws, scientific statements, administrative measures, and philosophical, moral, and philanthropic propositions that responds to an "urgent need" in a certain historical moment. In other words, an apparatus is a historically specific and dispersed system of power that produces and configures practices toward certain strategic and political ends. My use of Foucault's idea of apparatus enables me to move philosophical discussion about disability away from restrictive conceptualizations of it as (for instance) a personal characteristic or attribute, a property of given individuals, an identity, a difference, or a form of social oppression. In addition, my assumption that disability is an apparatus, in Foucault's sense, moves philosophical discussion of disability toward a more comprehensive conceptualization of it than the other conceptions of disability provide, a conceptualization of disability that is historicist and relativist and, hence, culturally sensitive in ways that other conceptions of it are not. As an apparatus, disability is a historically specific aggregate that comprises, constitutes, and is constituted by and through a complex and complicated set of discourses, technologies, identities, and practices that emerge from medical and scientific research, government policies and administrative decisions, academic initiatives, activism, art and literature, mainstream popular culture, and so on. Although some of the diverse elements of the apparatus of disability seem to have different and even conflicting aims, design strategies, and techniques of application, the elements of the apparatus are nevertheless co-constitutive and mutually reinforcing.

In other words, to understand disability as an apparatus is to conceive of it as a far-reaching and systemic matrix of power that contributes to, is inseparable from, and reinforces other apparatuses of historical force relations, such as settler colonialism, white supremacy, gender, and class. On this understanding, disability is not a metaphysical substrate, a natural, biological category, or a characteristic that only certain individuals embody or possess, but rather is a historically contingent network of force relations 
in which everyone is implicated and entangled and in relation to which everyone occupies a position. That is, to be disabled or nondisabled is to occupy a certain subject position within the productive constraints of the apparatus of disability. In the terms of this understanding of disability, there are no "people with disabilities" and "able-bodied people"; rather, there are "disabled people" and "nondisabled people." Just as people are variously racialized through strategies and mechanisms of the apparatus of race, but no one "has" a race or even a certain race and, furthermore, just as people are variously sexed through strategies and mechanisms of the apparatus of sex, but no one "has" a sex or even a particular sex, so too people are variously disabled or not disabled through the operations of the apparatus of disability, but no one "has" a disability or even a given disability. In short, disability (like race and sex) is not a nonaccidental attribute, characteristic, or property of individuals, not a natural biological kind (see Tremain ;2001, 2015, 2017a; Haslanger 2000, 2006, 2012; Spencer and Tremain 2017).

The apparatus of disability is expansive and expanding, differentially subjecting people to relatively recent forms of power on the basis of constructed perceptions and interpretations of (inter alia) bodily structure, appearance, style and pace of motility, mode of communication, emotional expression, mode of food intake, and cognitive character, all of which phenomena are produced and understood within a culturally and historically contingent frame and shaped by place of birth, place of residence, gender, education, religion, years lived, and so on. My analysis of the apparatus of disability treats these phenomena as the outcomes of contextually specific and performative relations of power rather than as transcultural and transhistorical objective and determined facts about humans. As I have indicated, furthermore, the argument that disability is an apparatus is premised on an understanding of the relation between power and causation that runs counter to current and emerging work in philosophy of disability and disability studies. For the conception of disability as an apparatus does not rely upon some variation of the assumption that impairment and disability could be taken up as politically neutral and value-neutral objects of inquiry were it not for disabling practices and policies of exclusion that the ideological requirements of power place upon them. This assumption is fundamental to the BSM (and most other extant sociopolitical approaches to disability) whose proponents argue that impairment is a politically neutral human characteristic on which disability, construed as a form of social oppression, is imposed. With the conception of disability as an apparatus, by contrast, no domain of impairment or disability exists apart from relations of power. Impairment and disability can never be freed from power, nor, 
furthermore, can there be a phenomenology that articulates these supposedly prediscursive domains. Power relations are not external to impairment and disability and their nexus in the apparatus of disability, but rather are integral to this relationship, constituting the knowledge and objects that these historical artifacts affect, as well as the artifacts themselves. Modern power is productive and diffused throughout society rather than merely repressive, operating downward from a central authority or institution.

Insofar as techniques of knowledge are not external to or separate from strategies of power, and inasmuch as knowledge-power relations are constitutive of the objects that they affect, my feminist philosophy of disability aims to identify and examine "especially dense transfer point[s] for relations of power" (Foucault 1978, 98) within philosophy that the apparatus of disability has produced, thereby contributing to its expansion and to the constitution of its naturalized elements, of which impairment is only one. Within the discipline of philosophy, the subfields of bioethics and cognitive science are most easily recognizable as domains within which the constitutive effects of the apparatus of disability are generated. I want to point out, however, that such sites of power can be identified across and throughout the discipline. Notice that Foucault's insight according to which knowledge-power relations are constitutive of the very objects that they are claimed to merely represent effectively dissolves the binary distinctions between (for instance) description and prescription, fact and value, and form and content. Among other things, the insight indicates that any given description is indeed a prescription for the formulation of the object (person, practice, or thing) to which it is claimed to innocently refer (Foucault 1980b, 1997). In other words, knowledge-power relations have not only brought impairment into being, but rather have brought it into being as a certain kind of thing, that is, as negative, as a natural disadvantage, as a problem to be corrected or rectified. Impairment has been problematized in philosophy, that is, has emerged as an area of investigation in philosophy (and elsewhere) only because productive relations of power established it as a possible object of inquiry and a particular kind of object of a particular kind of inquiry in the first place, inquiry that has been possible only because techniques of knowledge and discursive practices have been able to invest it as such. In short, various discourses within the discipline and profession of philosophy have contributed to the production of impairment and other elements of the apparatus of disability through the very inquiry into them in which philosophers engage.

The apparatus of disability and its naturalized foundation, impairment, are products and mechanisms of biopower, which, as Foucault pointed out, is a form of power that political philosophy has thus far largely ignored. 
Indeed, the apparatus of disability has been integral, indeed vital, to the strategies of this relatively recent form of power. In the January 11 lecture of his 1977-78 course at the Collège de France (subsequently published in English as Security, Territory, Population: Lectures at the College de France, 1977-1978), Foucault described biopower as "the set of mechanisms through which the basic biological features of the human species became the object of a political strategy, of a general strategy of power, or, in other words, how, starting from the eighteenth century, modern [W] estern societies took on board the fundamental biological fact that human beings are a species" (2007, 1). Biopower, Foucault wrote, is "what brought life and its mechanisms into the realm of explicit calculations and made knowledge-power an agent of transformation of human life" (1978, 143). Life - its enhancement, amplification, quality, duration, continuance, and renewal - has become an urgent economic and political concern that government policy and practice addresses to wrest management and control of it. Biopower's management of life has entailed the inauguration of a novel set of strategic measurements, including the ratio of births to deaths, the rate of fertility in the population, and the rate of reproduction, as well as a body of statistical knowledge and administrative cataloging of states of health and perceived threats to it. Through biopower, human biology has become the object of a political strategy (2007, 1).

\section{BIOPOWER AND NORMALIZATION}

The consolidation of the modern concept of "normal" legitimized and occurred in tandem with the new statistical knowledge and other techniques of population management that stemmed from biopower. As François Ewald (1991, 138) explains, the norm enabled biopower, "which aims to produce, develop, and order social strength," to steadily do the work that juridical modes of governance, characterized by forcible seizure, abduction, or repression, had done in the past. The norm accomplished this expansion by enabling discipline to develop from a simple set of constraints into a mechanism and by transforming the negative restraints of the juridical into the more positive controls of normalization (141). From the eighteenth century on, the function of technologies of normalization has been to isolate so-called anomalies in the population, which can be normalized through the therapeutic and corrective strategies of other, associated technologies. Technologies of normalization are not innocuous or even benevolent responses to these anomalies in the social body. On the contrary, technologies of normalization are instrumental to the systematic creation, identification, classification, and control of such anomalies; that 
is, they systematically contribute to the constitution of the perception of anomalies (such as impairment) and operate as mechanisms through which some subjects can be divided from others. Foucault introduced the term dividing practices to refer to modes of manipulation that combine a scientific discourse with practices of segregation and social exclusion to categorize, classify, distribute, and manipulate subjects who are initially drawn from a rather undifferentiated mass of people. Through these practices, subjects become objectivized as (for instance) mad or sane, sick or healthy, criminal or law abiding. Through these practices of division, classification, and ordering, furthermore, subjects become tied to an identity and come to understand themselves scientifically (Foucault 1982, 208).

Foucault regarded normalization as a central - if not the central - mechanism of biopower's management of life, the life of both the individual and the species. Biopower can thus be defined as a historically specific combination of normalization and population management conducted through vast networks of production and social control. Beginning in the eighteenth century, Foucault noted, the power of the normal has combined with other powers such as the law and tradition, imposing new limits upon them. The normal, he explained, was established as a principle of coercion through the introduction of standardized education; the organization of national medical professions and hospital systems that could circulate general norms of health; and the standardization of industrial processes and products and manufacturing techniques. Normalization thus became one of the great instruments of power at the close of the classical age, that is, the power that the norm harnessed has been shaped through the disciplines that began to emerge at this historical moment (Foucault 1977a, 184). For from the end of the eighteenth century, the indicators of social status, privilege, and group affiliation have been increasingly supplemented, if not replaced, by a range of degrees of normality that simultaneously indicate membership in a homogeneous social body (a "population") and serve to distinguish subjects from each other, to classify them, and to rank them in a host of hierarchies.

Foucault, in his writing on punishment (1977a) and his subsequent writing on the history of sexuality (1978), described how knowledges produced about the "normal" case become vehicles for the exercise of disciplinary force relations that target certain people. The etymology of the term normal offers clues to the relation between forms of power and the notion of normalcy. Ian Hacking (1990) notes that the first meaning of normal that current English dictionaries provide is something like "usual, regular, common, typical." This usage, according to the Oxford English Dictionary, became current after 1840, with the first citation of "normal, or typical" appearing 
in 1828. Hacking remarks that the modern sense of the word normal was not, however, furnished by education or cloistered study but rather by the study of life (1990, 161-62). In an illuminating discussion, Hacking asserts that the word normal became indispensable because it provided a way to be objective about human beings, especially given the inseparability of the notion of normal from its opposite, namely, the pathological. The word normal, he writes, "uses a power as old as Aristotle to bridge the fact/value distinction, whispering in your ear that what is normal is also all right" (160). Just as the concept of human nature is the hallmark of the Enlightenment, he argues, the word normal bears the stamp of the nineteenth century. Whereas in the past we sought to discover what human nature is, we now concern our selves with investigations that will tell us what is normal (161). Although the normal stands "indifferently for what is typical, the unenthusiastic objective average, it also stands for what has been, good health, and what shall be, our chosen destiny." "That," Hacking contends, "is why the benign and sterile-sounding word 'normal' has become one of the most powerful ideological tools of the twentieth century" (169). It is especially noteworthy for a feminist genealogical intervention into the problematization of disability that the modern usage of the word normal evolved in a medical context (165).

Hacking (1990) remarks that in the late 1700s the relation between the concepts of the pathological and the normal had been significantly reinvented. Disease came to be regarded as an attribute of individual organs rather than as a characteristic of the entire body. Pathology, likewise, was reconfigured, becoming the study of unhealthy organs rather than the study of sick or diseased bodies. Unhealthy organs could be investigated, in part, by the chemistry of fluids, such as urine or mucus, that actual living beings secreted. The concept of the normal, Hacking notes, came into being as the inverse of this concept of pathology: a given state of affairs or process of the body was normal if it was not associated with a pathological organ. In other words, the normal was secondary to, derivative of, and defined by the pathological. F. J. V. Broussais's principle - that life is a matter of excitation of tissue and disease is "irritation" of the tissue of a given organ - inverted this relation of entailment between the pathological and the normal (82). The pathological became defined as deviation from the normal, and all variation became characterized as variation from the normal state. Pathology was no longer conceived as different in kind from the normal, but rather as continuous with it (164). This new understanding of the normal and the pathological that emerged in the late 1700s is one, but only one, component of what I (2010; 2017a) refer to as "the diagnostic 
style of reasoning," a style of reasoning that has enabled the consolidation and expansion of biopower. Given the importance of statistical knowledge to the operations of biopower, it is not surprising that Broussais - to whom Auguste Comte, for one, attributes our modern understanding of the normal - was connected to the first use of statistical data to evaluate medical treatment (Hacking 1990, 81; 2002).

\section{NORMALIZATION IN BIOETHICS}

The notion of "normal species-typical functioning" that bioethicist Norman Daniels and his coauthors Daniel Brock, Allen Buchanan, and Daniel Wikler (Buchanan et al. 2000) have popularized in contemporary mainstream bioethics is a mechanism of normalization through approximation to a conception of normality. The idea of species-typical functioning does not, of course, originate from within the field of bioethics itself, but rather has been imported into that discourse from the work of philosopher of science Christopher Boorse (1977). Ronald Amundson (2005) has pointed out that although the use of the word typical in the term typical function seems to suggest statistical assessment - that is, what constitutes the common or usual function-Boorse intends the notion to imply the normal function of members of a species. Boorse claims that the distinction between "normal" and "abnormal" function is an empirically grounded implication of biomedical science. Normal and abnormal function are distinct natural kinds, objective facts of the natural world. Within Boorse's theory, Amundson notes, the notion of normal function carries a double implication. First, normal function is statistically common in the species; abnormal function is rare. Second, normal function is the most successful or (in Darwinian terms) the most fit. The claim is that the more an organism diverges from its species average, the worse it will function (Amundson 2005, 105; see also Amundson 2000).

Amundson (2005) argues that Boorse's contribution to this discussion in bioethics misrepresents biomedical science. Neither functional uniformity nor the association between statistical typicality and excellence of function, Amundson states, is a scientific discovery about the biological world. As Amundson explains it, information supplied from a wide number of biological disciplines suggests that we should expect a wide range of functional variation, not a narrow match between functional typicality and functional success. He points out, furthermore, that evolutionary biology does not imply functional uniformity as an outcome of evolution; rather, functional variability is a basic assumption of Darwinian natural selection. 
Conformity among members of a given species is not implied by the facts of developmental biology; rather, developmental plasticity and functional adaptation, he writes, suggest that we should expect variation in the functional organization of the bodies of species members, not strict conformity. As Amundson puts it, there is so much functional variation among humans and the variation is so multidimensional that the belief in an objective correlation between typicality and functional success is scientifically untenable (2005, 106-7).

Boorse presented his theory as an empirical claim about biology; nevertheless, it has been used to support normative consequences in the bioethical writings of Daniels, Brock, Buchanan, and Wikler, among others. These normative conclusions imply that disabled people have a lower quality of life, by virtue of impairment, and that such lives should be prevented. Amundson has argued, to the contrary, that these conclusions and indeed this entire discussion in biomedical ethics are biased against disabled people and the satisfaction of their civil rights because philosophers have failed to come to terms with the political conceptions of disability that the disabled people's movement has developed. Amundson has pointed out, furthermore, that these normative conclusions seem to be contradicted by a wealth of empirical data and first-person reports from disabled people who do not experience a lower quality of life than nondisabled people or experience a better quality of life than nondisabled people (Amundson 2000, 2005).

Given the historicist and relativist commitments that motivate my feminist philosophy of disability, I assume that there is no universal, timeless, and objective quality of life that can be analytically separated from the contingent circumstances in which people live. The idea that there can be a singular, evaluative quantification of "life" is a normalizing instrument of biopower that categorizes, ranks, differentiates, and distinguishes subjects within a population in order to homogenize - that is, normalize - the population. In other words, the idea of "quality of life," an idea that bioethicists such as Daniels and Brock have promoted, is an individualizing and totalizing technique of power, a technique that implicates academic bioethics in the apparatus of disability to an extent that no other subfield is implicated in it, although cognitive science and cognate fields increasingly gain ground in this regard. Indeed, I contend that the subfield of bioethics (including feminist bioethics and disability bioethics) - as a concerted enterprise - is a mechanism of biopower whose increasing institutionalization and legitimation in the university, in the discipline of philosophy, and in public policy (among other contexts) consolidate and conceal the fundamental role that this field of inquiry plays in biopolitical strategies of normalization and 
hence the government of populations. ${ }^{2}$ The subfield of bioethics, I want to argue, rationalizes (among other things) the proliferation and use of biotechnologies such as prenatal testing and screening and, in doing so, bioethics effectively contributes to the constitution of impairment (among other so-called anomalies) through the identification, evaluation, assessment, classification, and categorization of it, thereby expanding the purview of the apparatus of disability and extending its reach. The subfield of bioethics, I maintain, is a set of strategic discursive practices that works in the service of the mechanism of normalization and the government of conduct to eliminate impairments that medical, juridical, and administrative discourses claim to discover and manage, while simultaneously enabling these discourses to enlarge the scope of the broad outlines of the category of impairment itself.

Bioethics is generally regarded as the most suitable (if not the only) domain in philosophy for critical considerations about disability; however, bioethics actually operates as an area of philosophy whose guiding assumptions and discursive practices are significant obstacles to (1) acknowledgment that the questions - metaphysical, epistemological, political, and ethicalthat the apparatus of disability raises are genuinely philosophical, and (2) recognition that disabled philosophers who investigate these questions are credible philosophers. Indeed, bioethicists serve as gatekeepers, guarding the discipline from the incursion of critical philosophical work on disability and shielding the profession from an influx of disabled philosophers. Exceptions to this exclusion are of course admissible and even serve to legitimize both the subfield of bioethics and the discipline in general, typifying the polymorphism of the (neo)liberal governmentality - that is, its capacity to persistently engage in a practice of autocritique - from which the subfield of bioethics has emerged and enabling philosophy to proceed under the guise of political neutrality, objectivity, and disinterest (see Tremain 2017a).

The charge of "slippery-slope" reasoning that many bioethicists direct at critics of genetic technologies, physician-assisted suicide, and euthanasia is a stark example of the gatekeeping in which bioethicists engage. Many bioethicists - some of whom have substantial influence on hiring practices

\footnotetext{
${ }^{2}$ Some feminist philosophers of disability who aim to change the subfield of bioethics in ways that would make it more inclusive of philosophy of disability and less hostile to disabled people might feel disheartened by my remarks in this context and urge me to explain what course of action they should take. Although I indicate at the outset of this article that I do not make normative recommendations in it about how the problematization of disability in philosophy should be "resolved," I do make suggestions elsewhere about the way that critical philosophical work on the problematization of disability in philosophy and bioethics in particular might proceed. For instance, see Tremain (2017b; 2006).
} 
and publishing (among other things) in philosophy, as well as on public policy and public perceptions of their field - maintain that philosophers and theorists of disability (and disabled activists) who criticize the production of these technologies and practices produce fallacious arguments by using "slippery-slope reasoning" to advance their claims; thus, their positions, these bioethicists argue, ought not to be taken seriously (for instance, see Schüklenk et al. 2011). That is, bioethicists who argue in favor of physician-assisted suicide, euthanasia, and genetic technologies such as prenatal testing and screening imply that although the arguments that philosophers and theorists of disability advance to oppose these practices and technologies are politically motivated, ideological, and unsound, their own arguments in favor of these practices and technologies are disinterested (yet compassionate), objective (yet caring), and rigorous (yet flexible and sensitive) (see Tremain 2017a).

My argument, however, is that the critiques of physician-assisted suicide, euthanasia, and prenatal and other genetic technologies that bioethicists associate with slippery-slope reasoning astutely identify the incremental normalization of modern force relations that operates through the inculcation and utilization of a relatively recent kind of subjectivity; that is, I contend that the charge of slippery-slope reasoning that (many) bioethicists direct at critics of physician-assisted suicide, euthanasia, and genetic technologies results from the failure of these bioethicists to recognize that the critiques address the nature and operations of force relations under neoliberal governmentality, including the production of neoliberal subjects whose management and modification of biological life is taken as fundamental to selfhood and responsible citizenship (see Pitts-Taylor 2010). A certain coalescence and movement of force relations centred on the optimization of "life" - namely, biopower - has facilitated the incremental normalization of these medical technologies, practices, and the bioethical discourses co-constitutive with them in order to promote the life of a distinctive population while ensuring the elimination of others. Consider Foucault's remarks about the three main forms that technologies of government take in their development and history: first, a given technology of government takes the form of a dream or utopia; next, the dream of the technology of government develops into actual practices or rules to be used in real institutions; finally, the practices and rules of the technology of government become consolidated in the form of an academic discipline (Foucault 1988, 145-62; see also Hall 2015, 166-69; Hall 2016). I contend that Foucault's itinerary of the advance of a technology of government aptly explains the rise and growth of bioethics in the neoliberal university. 
Mainstream bioethicists assume that they should apply the allegedly universal and ahistorical principles of deontology, utilitarianism, and virtue ethics to medical situations, that is, they presuppose that these situations are occasions for the expression and application of pre-existing individualistic values such as autonomy, well-being, and liberty. I maintain, however, that the repeated iteration of these values in research agendas and clinical protocols is performative, repeatedly generating and configuring them anew (see also Hall 2015, 169; Hall 2016). My argument is that the academic discipline of bioethics is an institutionalized vehicle for the biopolitics of our time, that is, bioethics is a predictable product of biopower, a technology of government that provides intellectual resources designed to ensure the "strengthening" of a certain population and the eradication of others. A neoliberal governmentality of security - in support of which the apparatus of disability and other apparatuses have amalgamated - undergirds the academic field of bioethics and has motivated its emergence and elaboration, including the incessant production within the field of questions and concerns about putatively natural "disabilities" and the refinement of positions that rationalize their prevention and elimination (Tremain 2017a). In short, bioethics is a pernicious enterprise, a mechanism of racism against the abnormal, as Foucault (2007) referred to it. In a text that is both prescient and provocative, Foucault described racism against the abnormal as a racism not preoccupied with attacking members of another race, but rather with protecting the boundaries of the race, the only race that matters, the human race embodied in its "highest" representatives (see McWhorter 2009, 139-40). As Foucault remarks about the development of a technology of government suggest, bioethics, as a mechanism of racism against the abnormal, is the institutionalization of a modern regime of eugenics. Hence, the importance of Foucault for a feminist philosophy of disability that aims to subvert the individualized and medicalized conception of disability that has conditioned claims advanced in philosophy.

\section{REFERENCES}

Amundson, Ron. 2000. "Against Normal Function." Studies in the History and Philosophy of Biological and Biomedical Sciences 31C: 33-53.

- 2005. "Disability, Ideology, and Quality of Life: A Bias in Biomedical Ethics." In Quality of Life and Human Difference, edited by David Wasserman, Robert Wachbroit, and Jerome Bickenbach, 101-24. Cambridge: Cambridge University Press.

Barnes, Elizabeth. 2016. The Minority Body: A Theory of Disability. Oxford: Oxford University Press. 
Boorse, Christopher. 1977. "Health as a Theoretical Concept." Philosophy of Science 44: $542-73$.

Buchanan, Allen, Dan W. Brock, Norman Daniels, and Daniel I. Wikler. 2000. From Chance to Choice: Genetics and Fustice. Cambridge: Cambridge University Press.

Carlson, Licia. 2009. The Faces of Intellectual Disability: Philosophical Reflections. Indianapolis: Indiana University Press.

Dotson, Kristie. 2011. "Tracking Epistemic Violence, Tracking Practices of Silencing." Hypatia: A Fournal of Feminist Philosophy 26 (2): 236-57.

- 2012. "A Cautionary Tale: On Limiting Epistemic Oppression." Frontiers 33 (1): $24-47$.

Dworkin, Ronald. 1981a. "What is Equality? Part 1: Equality of Welfare." Philosophy and Public Affairs 10 (3): 185-246.

- 1981b. "What is Equality? Part 2: Equality of Resources." Philosophy and Public Affairs 10 (4): 283-345.

Ewald, François. 1991. "Norms, Discipline, and the Law." In Law and the Order of Culture, edited by Robert Post, 138-61. Berkeley: University of California Press.

Foucault, Michel. 1977a. Discipline and Punish: The Birth of the Prison. Translated by Alan Sheridan. New York: Vintage Books.

—. 1977b. "Nietzsche, Genealogy, History." In Language, Counter-memory, Practice: Selected Essays and Interviews by Michel Foucault. Edited by Donald F. Bouchard, translated by Donald F. Bouchard and Sherry Simon, 139-64. Ithaca, NY: Cornell University Press.

- 1978. The History of Sexuality, Vol. 1: An Introduction. Translated by Robert Hurley. New York: Vintage Books.

. 1980a. "The Confession of the Flesh." In Power/Knowledge: Selected Interviews and Other Writings, 1972-1977, edited by Colin Gordon, 194-228. New York: Pantheon Books.

- 1980b. "Two Lectures." In Power/Knowledge: Selected Interviews and Other Writings, 1972-1977, edited by Colin Gordon, 78-108. New York: Pantheon Books.

_. 1982. "The Subject and Power." Appended to Michel Foucault: Beyond Structuralism and Hermeneutics, 2nd ed., edited by Hubert L. Dreyfus and Paul Rabinow, 208-26. Chicago: University of Chicago Press.

—. 1988. "Power, Moral Values, and the Intellectual." History of the Present 4.

—. 1997. "What Is Enlightenment?" In The Essential Works of Michel Foucault, 1954-1984, Ethics: Subjectivity, and Truth, edited by Paul Rabinow, 303-19. New York: The New Press.

_ 2003a. "Polemics and Problematizations: An Interview with Michel Foucault." In The Essential Foucault: Selections from Essential Works of Foucault, 1954-1984, edited by Paul Rabinow and Nikolas Rose, 10-24. New York: The New Press.

- 2003b. "Society Must Be Defended": Lectures at the Collège de France, 1975-1976. Edited by Mauro Bertani and Alessandro Fontana, translated by David Macey. New York: Picador.

- 2007. Security, Territory, Population: Lectures at the Collège de France, 1977-1978. Edited by Michel Senellart, translated by Graham Burchell. New York: Palgrave Macmillan. 
Fraser, Nancy. 1989. Unruly Practices: Power, Discourse, and Gender in Contemporary Social Theory. Cambridge: Polity Press.

Gilman, Sander L., and James M. Thomas. 2016. Are Racists Crazy? How Prejudice, Racism, and Antisemitism Became Markers of Insanity. New York: New York University Press.

Hacking, Ian. 1990. The Taming of Chance. Cambridge: Cambridge University Press. - 2002. Historical Ontology. Cambridge, MA: Harvard University Press.

Hall, Melinda. 2015. "Continental Approaches in Bioethics." Philosophy Compass 10 (3): $161-72$.

- 2016. The Bioethics of Enhancement: Transhumanism, Disability, Bioethics. Lanham, MD: Rowman and Littlefield.

Harding, Sandra. 1986. The Science Question in Feminism. Ithaca, NY: Cornell University Press.

- 1991. Whose Science? Whose Knowledge? Thinking from Women's Lives. Ithaca, NY: Cornell University Press.

- 2015. Objectivity and Diversity: Another Logic of Scientific Research. Ithaca, NY: Cornell University Press.

Hartsock, Nancy C. M. 1983. "The Feminist Standpoint: Developing the Ground for a Specifically Feminist Historical Materialism." In Discovering Reality, edited by Sandra Harding and Merrill B. Hintikka, 283-310. Dordrecht: D. Reidel.

Haslanger, Sally. 2000. "Gender and Race: (What) Are They? (What) Do We Want Them To Be?" Noûs 34 (1): 31-55.

- 2006. "Philosophical Analysis and Social Kinds: What Good Are Our Intuitions?" Aristotelian Society Supplementary 80 (1): 89-118.

- 2012. Resisting Reality: Social Construction and Social Critique. New York: Oxford University Press.

Kittay, Eva Feder. 1999. Love's Labor: Essays on Women, Equality, and Dependency. New York: Routledge.

McWhorter, Ladelle. 2009. Racism and Sexual Oppression: A Genealogy. Bloomington: Indiana University Press.

Nietzsche, Friedrich. [1887] 1999. On the Genealogy of Morals. Translated by Douglas

Smith. New York: Oxford University Press.

PhilPapers: Online Research in Philosophy. n.d. https://philpapers.org/

Pitts-Taylor, Victoria. 2010. "The Plastic Brain: Neoliberalism and the Neuronal Self." Health 14 (6): 635-52.

Prinz, Jesse J. 2012. Beyond Human Nature: How Culture and Experience Shape the Human Mind. New York: W. W. Norton.

Rawls, John. 1971. A Theory of Justice. Cambridge, MA: Belknap Press of Harvard University Press.

Roberts, Dorothy. 1998. Killing the Black Body: Race, Reproduction, and the Meaning of Liberty. New York: Vintage Books.

2012. Fatal Invention: How Science, Politics, and Big Business Re-create Race in the Twenty-First Century. New York: The New Press.

- 2016. "The Ethics of the Biosocial: The Old Biosocial and the Legacy of Unethical Science." Tanner Lectures on Human Values, Mahindra Humanities Center, Harvard University. November 2, 2016. Cambridge, MA. 
Schüklenk, Udo, Johannes J. M. van Delden, Jocelyn Downie, Sheila McLean, Ross Upshur, and Daniel Weinstock. 2011. "End-of-Life Decision-Making in Canada: The Report by the Royal Society of Canada Expert Panel on End-of-Life DecisionMaking." Bioethics 25 (1): 1-4.

Sen, Amartya. 1979. "Equality of What?" The Tanner Lectures on Human Values. Delivered at Stanford University. Standford, CA.

Silvers, Anita. 1995. "Reconciling Equality to Difference: Caring (F)or Justice for People with Disabilities". Hypatia: A Journal of Feminist Philosophy 10 (1): 30-55.

Spencer, Quayshawn, and Shelley Tremain. 2017. "Dialogues on Disability: Shelley Tremain Interviews Quayshawn Spencer." Discrimination and Disadvantage (blog). http://philosophycommons.typepad.com/disability_and_disadvanta/2017/05/dialogues-on-disability-shelley-tremain-interviews-quayshawn-spencer.html

Tremain, Shelley. 1996. "Dworkin on Disablement and Resources." The Canadian Fournal of Law and Furisprudence: An International Fournal of Legal Thought 9 (2): 343-59.

- 2001. "On the Government of Disability." Social Theory and Practice 27 (4): $617-36$.

- 2006. "Reproductive Freedom, Self-regulation, and the Government of Impairment In Utero". Hypatia: A Journal of Feminist Philosophy 21 (1): 35-53.

- 2010. "Biopower, Styles of Reasoning, and What's Still Missing from the Stem Cell Debates." Hypatia: A Fournal of Feminist Philosophy 25 (3): 577-609.

—. 2013. "Introducing Feminist Philosophy of Disability." Disability Studies Quarterly 33 (4).

- 2015. "This is What a Historicist and Relativist Feminist Philosophy of Disability Looks Like." Foucault Studies 19 (June): 7-42.

. 2017a. Foucault and Feminist Philosophy of Disability. Ann Arbor: University of Michigan Press.

- 2017b. Symposium on Shelley Tremain's Foucault and Feminist Philosophy of Disability. Discrimination and Disadvantage (blog). http://philosophycommons.typepad. com/disability_and_disadvanta/2017/11/symposium-on-shelley-tremains-foucault-and-feminist-philosophy-of-disability-tremain.html

Wendell, Susan. 1996. The Rejected Body: Feminist Reflections on Disability. New York: Routledge.

Wylie, Alison. 2003. "Why Standpoint Matters." In Science and Other Cultures: Issues in Philosophies of Science and Technology, edited by Robert Figueroa and Sandra Harding, 26-46. New York: Routledge. 